\title{
PREVALENSI STATUS GIZI PADA SISWA-SISWI SMK N PRINGKUKU KABUPATEN PACITAN
}

\author{
[Prevalence of Nutrition Status In Students of SMK N Pringkuku Pacitan] \\ Novian Wely Asmoro*, A.I. Niken Tari, dan Afriyanti \\ Program Studi Teknologi Hasil Pertanian, Fakultas Pertanian, Universitas Veteran Bangun Nusantara, Sukoharjo \\ *email: novianwelyasmoro@gmail.com
}

Diterima 7 September 2017/ Disetujui 4 November 2017

\begin{abstract}
School-aged teenagers, in particular, have a habit and the pattern of food consumption is often irregular and does not pay attention to the pattern of good and balanced consumption. The condition of unbalanced consumption patterns can affect individual nutritional status. Body mass index measurement (BMI) is related to the prevalence of nutritional status in students of SMK N Pringkuku Kab. Pacitan is used as a general description of nutritional conditions within the school environment. Nutrition status data obtained from the calculation of height and weight and then calculated body mass index (BMI), and data related to healthy habits and lifestyle obtained from the filling of questionnaires by respondents. The results showed that there were students with less nutritional status, normal nutritional status, more nutritional status, and obesity were $25.44 \%, 58.18 \% 10.91 \%$ and $5.45 \%$ respectively with the condition related to sex and general breakfast habits and the frequency of eating a day showed $72.09 \%$ of students behaved well, while $27.91 \%$ of students behaved eating is not good.
\end{abstract}

Keywords: body mass index, consumption patterns, nutrition, students

\section{ABSTRAK}

Remaja usia sekolah khususnya memilikikebiasaan dan pola konsumsi makanan sering tidak teratur serta tidak memperhatikan pola konsumsi yang baik dan seimbang. Kondisi pola konsumsi yang tidak seimbang dapat berpengaruh pada status gizi individu. Pengukuran body mass index (BMI) terkait dengan prevalensi status gizi pada siswa SMK N Pringkuku Kab. Pacitan digunakan sebagai gambaran umum kondisi gizi dilingkungan sekolah. Data status gizi diperoleh dari perhitungan tinggi badan dan berat badan kemudian dilakukan perhitungan body mass index (BMI), dan data terkait kebiasaan-kebiasaan dan pola hidup sehat diperoleh dari pengisian kuisoner oleh responden. Hasil penelitian menunjukan terdapat siswa dengan status gizi kurang, status gizi normal, status gizi lebih dan obesitas berturut-turut sebanyak $25,44 \%$, $58,18 \% 10,91 \%$ dan $5,45 \%$ dengan kondisi tersebut berhubungan dengan jenis kelamin serta secara umum kebiasaan sarapan pagi dan frekuensi makan dalam sehari menujukan $72,09 \%$ siswa berperilaku makan baik, sedangkan $27,91 \%$ siswa berperilaku makan tidak baik.

Kata kunci : body mass index, gizi, pola konsumsi,siswa

\section{PENDAHULUAN}

Jumlah penduduk Indonesia yang telah mencapai 250 juta jiwa pada tahun 2016, didominasi oleh usia produktif serta Anak-anak dan remaja usia 15-24 tahun mencapai $21 \%$ dari total jumlah populasi penduduk Indonesia(BPS, 2016). Salah satu fokus pembangunan Masyarakat di bidang kesehatan adalah terkait dengan situasi gizi masyarakat yaitu kecukupan asupan energi penduduk Indonesia. Dalam Peraturan Menteri Kesehatan Nomor 75 Tahun 2013, Angka Kecukupan Gizi (AKG) merupakan suatu kecukupan rata-rata zat gizi setiap hari bagi semua orang menurut golongan umur, jenis kelamin, ukuran tubuh, aktifitas tubuh untuk mencapai derajat kesehatan yang optimal. Rata-rata kecukupan energi dan protein yang dianjurkan bagi penduduk Indonesia sebesar 2.150 kilo kalori dan 57 gram per orang per hari. Sampai dengan tahun 2014, rerata tingkat kecukupan energi penduduk Indonesia hanya sebesar $76,6 \%$ dengan $45,7 \%$ penduduk Indonesia mengonsumsi energi $\leq 70 \%$ AKE dan $5,9 \%$ penduduk mengonsumsi energi $\geq 130 \%$ AK (Kemenkes, 2016).

Makanan merupakan suatu kebutuhan pokok untuk pertumbuhan dan perkembangan tubuh, khusunya bagi remaja usia sekolah kekurangan konsumsi makanan baik dari segi jumlah maupun gizinya, akan menyebabkan gangguan proses metabolisme tubuh, yang mengarah pada timbulnya suatu penyakit. Kondisi ketidak seimbangan gizi masih banyak terjadi pada masyarakat Indonesia sehingga mengakibatkan dampak-dampak lain seperti tingkat kematian ibu dan bayi, tingkat 
kesehatan balita dan anak-anak, meningkatnya penyakit tidak menular seperti Diabetes Melitus, Jantung, Obesitas dan lain-lain. Selain itu, status gizi pada anak-anak dan remaja khususnya juga berpengaruh terhadap kesehatan seperti obesitas, anemia, bahkan konsentrasi belajar siswa dapat terganggu karena kesalahan pola konsumsi(Perdana \& Hardinsyah, 2013; Pujiati et al., 2015; Seprianty et al., 2015; Restuti \& Susindra, 2016).

Body mass index (BMI) dapat digunakan untuk penilaian status gizi, BMI merupakan pengukuran secara statistik danperbandingan antara berat dan tinggi tubuh dari seseorang. Skala BMI dibagi dalam 4 kategori yaitu $\leq 18.4$ (slim), 18.4-24.9 (normal), 25-29.9 (overweight), and $\geq 30$ (obese)(WHO, 2015). Status BMI pada masing-masing individu dipengaruhi oleh berbagai faktor, termasuk asupan gizi. Asupan gizi tubuh tidak dapat terpenuhi dari satu jenis makanan saja, tetapi harus dipenuhi dari makanan jenis lain sehingga memberikan kelengkapan dari segi sumber gizinya. Pada anak usia remaja konsumsi makanan kadang kala tidak teratur dan tidak memperhatikan pola konsumsi yang seimbang. Sehingga peningkatan pemahaman masyarakat khususnya remaja usia sekolah terhadap gizi terkait dengan status gizi dan pola konsumsi perlu dilakukan sehingga masing-masing individu dapat mengontrol pola konsumsi dan asupan gizinya(Cyril et al., 2016; Rada, 2016; Wattimena \& Defi, 2017)

Penelitian mengenai kebiasaan makan pada remaja di Romania usia 18-30 tahun menunjukan hasil, $19,7 \%$ mengalami kelebihan berat badan dan obesitas, sementara itu $11,6 \%$ justru mengalami kekurangan berat badan. Kondisi tersebut disebabkan oleh beberapa faktor antara lain jenis kelamin, kebiasaan tidak sarapan tetapi justru konsumsi cemilan manis, snack, dan minuman berenergi(Rada, 2016). Konsumsi makanan pada individu berpengaruh terhadap status gizi seseorang. Asupan utama bagi tubuh adalah sumber energi, apabila terjadi kekurangan pada asupan energi dari kebutuhan karena perilaku makan yang tidak baik berpotensi terjadinya penurunan status gizi.

Hasil penelitian Pujiati et al. (2015) menunjukkan pada responden remaja putri sebanyak 25 responden $(39,1 \%)$ berperilaku makan dengan baik, sedangkan 37 responden $(60,9 \%)$ yang perilaku makannya tergolong tidak baik. Hal ini disebabkan karena pola perilaku makan yang tidak teratur.Pada penelitian lain yang dilakukan oleh Ilham et al. (2017) pada responden mahasiswa Fakultas Sains dan Teknologi UIN Sunan Ampel Surabaya, menunjukkan adanya hubungan yang signifikan antara konsumsi energi, konsumsi protein dan pengetahuan terhadap status gizi BMI. Sebanyak $8.3 \%$ responden diidentifikasi masuk kedalam katagori obesitas I.

Tujuan dari penelitian ini adalah untuk mengetahui pengaruh pola konsumsi khususnya pada siswa siswi di SMK $\mathrm{N}$ Pringkuku Pacitan terhadap status gizi yang diukur menggunakan parameter Body Mass Index.

\section{METODOLOGI}

Responden dalam penelitian ini adalah 55 siswa siswi kelas XII SMK Pringkuku kabupaten Pacitan. Instrumen yang akan digunakan pada penelitian ini antara lain kuesioner untuk mengumpulkan data jenis kelamin, pengetahuan nutrisi, kebiasaan makan, pola konsumsi makanan dan kebiasaan-kebiasaan terkait dengan pola hidup sehat. Alat yang digunakan antara lain pengukur barat badan dengan ketelitian 0,1 dan alat pengukur tinggi badan. Pengumpulan data tinggi dan berat badan siswa dilakukan secara langsung dan data orang tua siswa diambil dengan memberikan kuisioner yang akan diisi oleh siswa.

Data status gizi diperoleh dari perhitungan tinggi badan dan berat badan kemudian dilakukan perhitungan body mass index (BMI) dimana $\mathrm{BMI}=(\mathrm{BB}(\mathrm{Kg})) /(\mathrm{TB} \times \mathrm{TB}$ $(\mathrm{m})$ ). Hasil perhitungan BMI dikelompokan kedalam skala BMI yang dibagi dalam 4 kategori yaitu $\leq 18.4$ (slim), 18.4-24.9 (normal), 25-29.9 (overweight), and $\geq 30$ (obese) (WHO, 2015). Data akan dianalisis menggunakan program Microsoft Excel, kemudian disajikan dalam bentuk tabel frekuensi dan diagram yang disajikan dalam bentuk deskriptif.

\section{HASIL \& PEMBAHASAN}

Hasil penelitian disajikan dalam bentuk deskriptif pada responden Siswa-siswiSMK N Pringkuku sebanyak 55 siswa. Responden terdiri atas siswa perempuan sebanyak $78,18 \%$ dan siswa laki-laki sebanyak $21,82 \%$. Hasil pengisian kuisioner terkait dengan kebiasaan sarapan pagi dan frekuensi makan dalam sehari menujukan $72,09 \%$ siswa 
berperilaku makan baik, sedangkan 27,91\% siswa berperilaku makan tidak baik. Karakteristik siswa dan orang tua siswa dari hasil pendataan dan kuisioner pada penelitian ini dapat dilihat pada Tabel 1.

Tabel 1. Karakteristik Siswa dan Orang Tua Siswa

\begin{tabular}{lc}
\hline \multicolumn{1}{c}{ Variabel } & $\begin{array}{c}\text { Jumlah } \\
(\mathbf{\%})\end{array}$ \\
\hline Karakteristik Siswa & \\
Jenis kelamin Laki-laki & 21,82 \\
Jenis kelamin Perempuan & 78,18 \\
Perilaku Makan & \\
Baik & 72,09 \\
Tidak baik & 27,91 \\
Latar Belakang Pendidikan & \\
Orang Tua & \\
SD & 45,24 \\
SMP & 28,57 \\
SMA & 19,05 \\
Sarjana & 7,14 \\
Latar Belakang Pekerjaan & \\
Orang Tua & \\
Buruh & \\
Petani & 4,76 \\
Swasta & 52,38 \\
PNS & 33,33 \\
\hline
\end{tabular}

Penelitian khusus tidak menjelaskan mengenai hubungan pendidikan dan pekerjaan kepala keluarga. Pada Tabel 1, latar pendidikan orang tua siswa $45,24 \%$ lulusan SD, dan SMA-Sarjana hanya 26,19\%. Asumsi peneliti semakin tinggi pendidikan, maka keluarga akan lebih memahami mengenai kondisi gizi anggota keluarga tersebut, sehingga kebutuhan akan gizi lebih diperhatikan sejalan dengan peneitian Seprianty et al. (2015) kondisi gizi buruk dan gizi kurang pada anak kelas 3 SD N 1 Sungai lilin lebih banyak dialami oleh anak dengan pendidikan terakhir ayah SD sebesar $20,8 \%$ dari responden.

Secara umum keluarga memiliki faktor penting dalam mempengaruhi status gizi anak atau remaja. Pada penelitian Cyril et al. (2016) rendahnya peran dan fungsi keluarga dalam mengatur kebiasaan makan anak-anak menyebabkan peningkatan BMI yaitu cendrung ke obesitas karena hal tersebut terkait dengan pola makan dan pemilihan jenis makanan. Hal tersebut terkait juga dengan pekerjaan kepala keluarga dan pendapatan keluarga berpengaruh terhadap status gizi.

\section{Status Gizi}

Berdasarkan hasil pengukuran dan perhitungan body mass index (BMI) menunjukan status gizi siswa yang dihitung berdasarkan standarWHO (2015) dari responden 55 siswa-siswi SMK N Pringkuku memperlihatkan bahwa terdapat 32 siswa $(58,18 \%)$ dengan status gizi normal dan 14 siswa $(25,44 \%)$ dengan status gizi kurang, 6 siswa $(10,91 \%)$ memiliki status gizi lebih, 3 siswa $(5,45 \%)$ dengan status obesitas.

Status gizi seseorang dapat dipengaruhi oleh banyak hal terkait dengan pola konsumsi, tingkat sosial ekonomi, dan kebiasaan/aktivitas fisik. Berdasarkan penelitian Hajare et al. (2016) menemukan bahwa siswa dengan prevalensi status gizi lebih sebanyak $5.84 \%$ dari responden dan obesitas sebanyak $0.35 \%$. Berdasarkan analisis statistic, kondisi gizi lebih dipengaruhi oleh tingginya status ekonomi, penurunan aktivitas fisik, peningkatan konsumsi junk food dan lama waktu menonton televise/computer. Penelitian Ilham et al. (2017) menyatakan bahwa perbedaan prevalensi status gizi terjadi dipengaruhi oleh pola konsumsi asupan energi dan protein serta pengetahuan responden mengenai BMI.

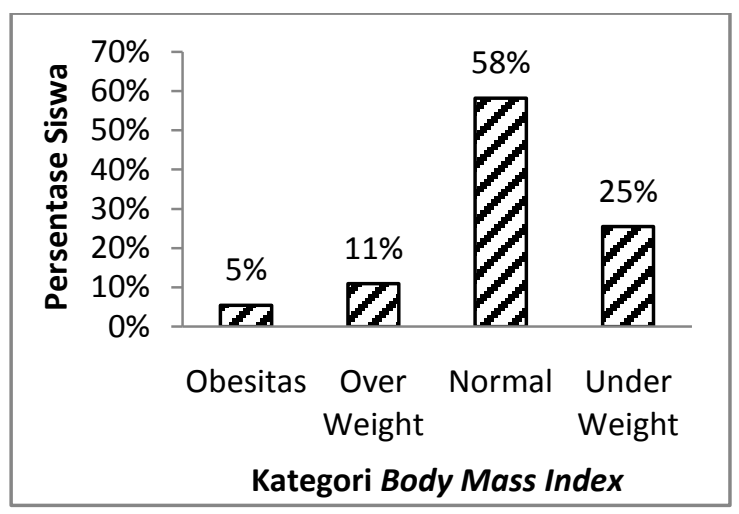

Gambar 1. Grafik Body Mass Index Siswa SMK N Pringkuku Pacitan.

\section{Jenis Kelamin}

Hasil penelitian berdasarkanjenis kelamin siswa menunjukan perbedaan prevalensi status gizi dari setiap tingkatan berdasarkan perhitungan BMI. Data penelitian ini, siswa laki- laki lebih banyak mengalami prevalensi gizi kurang $(41,67 \%)$ dari pada siswa perempuan (20,9\%), pada siswa perempuan lebih banyak memiliki prevalensi gizi lebih dan obesitas (7\%) sedangkan siswa laki-laki tidak ada yang memiliki prevalensi obesitas. Hasil analisis statistik korelasi menunjukan nilai hubungan antara status BMI dan jenis kelamin memiliki pengaruh yang signifikan (nilai sig. 0,043<a=0,05). Penyebab perbedaan kecendrungan nilai BMI 
pada siswa laki-laki dan perempuan dimungkinkan karena siswa laki- laki memiliki aktifitas fisik yang lebih tinggi dibandingkan dengansiswa perempuan, sehingga terjadi perbedaan kebutuhan energi yang harus dipenuhi atau diperlukan.

Sejalan dengan penelitian Chou \& Chen (2017) bahwa BMI dipengaruhi oleh level aktivitas fisik, kebiasaan dan pola makan yang dilakukan pada siswa-siswi SLTP di Taiwan. Pada penelitian Hajare et al. (2016) yang dilakukan pada siswa-siswi SMA juga memiliki kecendrungan prevalensi gizi lebih pada siswa perempuan lebih tinggi (6,53\%) dibandingkan pada siswa laki-laki (5,31\%). Kecendrungan siswa mengalami prevalensi gizi lebih dan obesitas tersebut disebabkan karena faktor kebiasaan dan gaya hidup serta menurunnya aktivitas fisik pada siswa. Secara lengkap data status gizi berdasarkan jenis kelamin dapat dilihat pada Tabel 2.

\section{Perilaku Hidup Sehat}

Hasil penelitian secara keseluruhan prevalensi status gizi pada siswa SMK $\mathrm{N}$ Pringkuku menunjukan hanya $58,18 \%$ siswa dengan prevalensi status gizi normal, 25,44\% siswa mengalami prevalensi gizi kurang dan sisanya mengalami gizi lebih dan obesitas. Kondisi status gizi pada siswa dan secara umum dipengaruhi oleh kebiasaan-kebiasaan dan perilaku hidup sehat. Data penelitian terhadap responden siswa dideskripsikan pada Gambar 2. grafik perilaku hidup sehat responden. Pada grafik dideskripsikan beberapa perilaku yang dilakukan oleh siswasiswi antara lain pola makan 3 kali dalam sehari (sebanyak 72\%), kebiasaan sarapan (74\%), pernah menjalani diet (14\%), pengontrolan berat badan setiap bulan $(7 \%)$, dan kebiasaan minum putih. Pada penelitian yang dilakukan oleh Perdana \& Hardinsyah (2013) terkait dengan kebiasaan sarapan pada anak-anak di Indonesia menunjukan bahwa lebih dari separuh (69.6\%) responden anak Indonesia masih belum mengonsumsi sarapan sesuai dengan anjuran gizi seimbang dari segi jenis, jumlah dan mutu sarapan.

Perilaku makan yang tidak baik tersebut juga akan membawa dampak pada prevalensi status gizi. Penelitian yang dilakukan pada remaja di kota Pekanbaru sebanyak 60,9\% melakukan perilaku makan yang tidak baik berpengaruh terhadap status gizi (Pujiati et al. 2015). Selain itu peningkatan konsumsi gula dan lemak serta penurunan aktivitas fisik pada anak-anak karena lebih banyak menonton $\mathrm{TV}$, bermain computer dan HP mendorong kecendrungan meningkatnya prevalensi obesitas pada anak-anak (Chou \& Chen 2017).

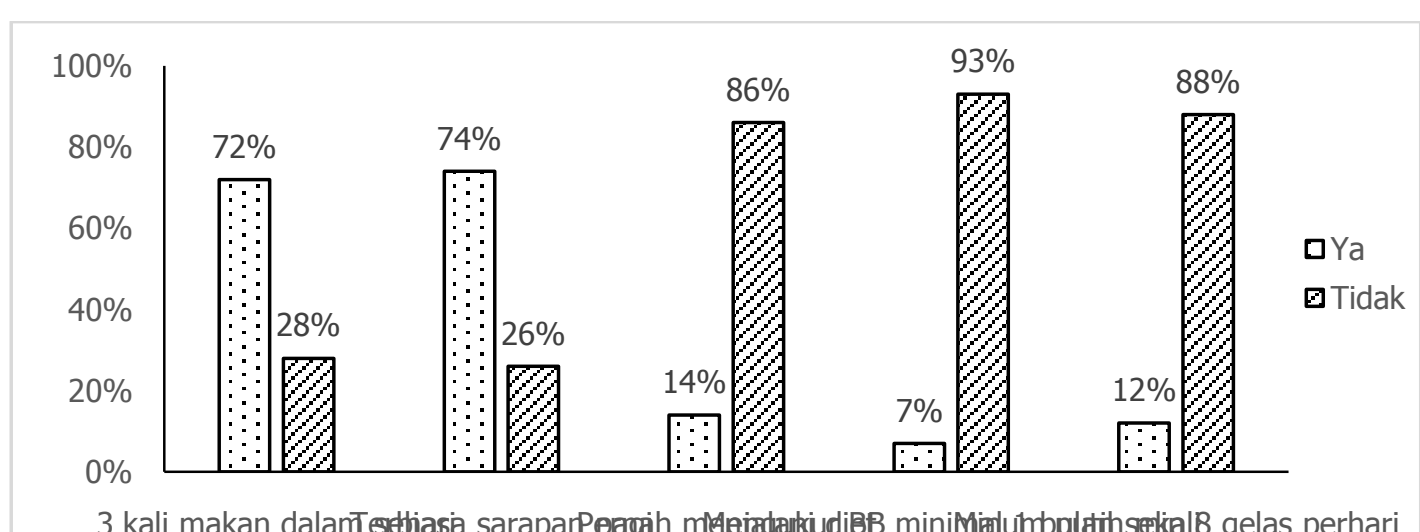

Gambar 2. Grafik perilaku hidup sehat pada siswa SMK N Pringkuku

Tabel 2. Hubungan Prevalensi Status Gizi dengan Jenis Kelamin

\begin{tabular}{|c|c|c|c|c|c|c|}
\hline \multirow[b]{2}{*}{ Jenis Kelamin } & \multirow[b]{2}{*}{ N \% } & \multicolumn{4}{|c|}{ Prevalensi Status Gizi (\%) } & \multirow[b]{2}{*}{ P value } \\
\hline & & $\begin{array}{c}\text { Gizi } \\
\text { kurang }\end{array}$ & $\begin{array}{c}\text { Gizi } \\
\text { Normal }\end{array}$ & Gizi lebih & Obesitas & \\
\hline Laki-laki & 21,82 & 41,67 & 50 & 8,33 & 0 & \\
\hline Perempuan & 78,18 & 20,9 & 60,5 & 11,66 & 7 & \\
\hline
\end{tabular}

*nilai pearson correlation0,274* 


\section{KESIMPULAN}

Hasil penelitian status gizi pada siswa siswi SMK N Pringkuku Kab. Pacitan dapat diambil kesimpulan bahwa terdapat siswa dengan status gizi kurang sebanyak $25,44 \%$, sebanyak $10,91 \%$ dan $5,45 \%$ dengan status gizi lebih dan obesitas kondisi tersebut berhubungan dengan jenis kelamin. Secara umum kebiasaan sarapan pagi dan frekuensi makan dalam sehari menujukan $72,09 \%$ siswa berperilaku makan baik, sedangkan 27,91\% siswa berperilaku makan tidak baik.

\section{UCAPAN TERIMAKASIH}

Terimakasih diucapkan kepada Lembaga Penelitian dan Pengabdian Masyarakat (LPPM) Universitas Veteran Bangun Nusantara Sukoharjo atas dukungan secara pendanaan pada kegiatan penelitian yang dilakukan melalui skema pendanaan internal Universitas Kompetitif Bidang IImu 2017.

\section{DAFTAR PUSTAKA}

BPS. 2016. Data Penduduk Indonesia, Available at: http//www.bps.go.id. [Diakses Januari 2017].

Chou L dan ChenM.2017. Influencing Factors of the Body Mass Index of Elementary Students in Southern Taiwan. International Journal of Environmental Research and Public Health, 14(220): 111.

Cyril S, Halliday J, Green J and Renzaho AMN. 2016. Relationship between body mass index and family functioning, family communication, family type and parenting style among African migrant parents and children in Victoria, Australia : a parent-child dyad study. $B M C$ Public Health, 16(707): 1-10. Available at: http://dx.doi.org/10.1186/s12889016-3394-1.

Hajare ST, Deoke AR \& Saoji PA. 2016. Life style profile of High School students and its association with Body Mass Index in Nagpur city , Central India. Indian Journal Of Community Health, 28(3): 3-
8.

Ilham, Oktorina S\& As'at MRH.2017. Hubungan Asupan Energi dan Protein Terhadap Indeks Massa Tubuh Mahasiswa Studi Kasus pada Mahasiswa UIN Sunan Ampel Surabaya. Jof Health Science and Prevention, 1(2): 97-106.

Kementerian Kesehatan. 2016. Situasi Gizi di Indonesia. Infodatin Kemenkes RI.

Perdana F \& Hardinsyah. 2013. Analisis Jenis, Jumlah, dan Mutu Gizi Konsumsi Sarapan Anak Indonesia. J Gizi dan Pangan, 8(1): 39-46.

Pujiati, Arneliwati \& Rahmalia, S., 2015. Hubungan Antara Perilaku Makan Dengan Status Gizi Pada Remaja Putri. JOM, 2(2), p.1345-.

Rada C.2016. Body Mass Index and Eating Habits in Young Adults from Romania. International Journal of Medical Research \& Health Sciences, 5(5): 42-50.

Restuti AN \& Susindra Y.2016. Hubungan antara Asupan Zat Gizi dan Status Gizi dengan Kejadian Anemia pada Remaja Putri di SMK Mahfilud Durror II Jelbuk. In Seminar Hasil Penelitian dan Pengabdian Masyarakat Dana BOPTN Tahun 2016. pp. 74-80.

Seprianty V, Tjekyan RMS \& Thaha MA. 2015. Status Gizi Anak Kelas III Sekolah Dasar Negeri 1 Sungaililin. Jurnal Kedokteran dan Kesehatan, 2(1): 129-134.

Wattimena RH\& DefiIR. 2017. Correlation between body mass index, gender, and skeletal muscle mass cut off point in Bandung. International Journal of Integrated Health Sciences, 5(2): 47-51.

WHO. 2015. World Health Organization (WHO) [Internet]. BMI classification. Available at: http://apps.who.int/bmi/index.jsp?introPa ge=intro_3.html. 